
Діяльність прокурора на стадії досудового розслідування у кримінальному провадженні
на підставі угод з урахуванням досвіду іноземних країн

\author{
Наливайко С. О. \\ кандидат юридичних наук \\ orcid.org/0000-0002-7597-8762 \\ EvgeniyNalivaiko111@gmail.com
}

\author{
Ключові слова: \\ інститут угод, угода про \\ примирення, угодапровизнання \\ винуватості, процесуальний \\ керівник.
}

Реформування кримінального процесу висунуло нові вимоги до українського суспільства й держави. Зміни, що відбуваються, своєю останньою метою ставлять в основу кримінального процесу людину, іiі права й свободи, які визнаються найвищими цінностями й визначають зміст і спрямованість діяльності держави. Україною обраний євроінтеграційний курс, за задумом спрямований на можливість вивчення та застосування найкращих інститутів кримінального процесу, що тривалий час діють у зарубіжних країнах.

Одним із таких інститутів у разі вірного застосування та використання, на наше переконання, є інститут угод у кримінальному провадженні, який за своєю сутністю повинен значно скоротити розгляд кримінальних проваджень і спростити розслідування по тяжким та особливо тяжким злочинам, а отже, зменшити навантаження на процесуального керівника й сприяти інтересам суспільства.

Попри те, що такий інститут у нашій державі діє з 2012 року, навіть зараз не можна стверджувати про сталу практику й чітке регламентування процесуальних норм під час його застосування. На нашу думку, це зумовлено декількома факторами, до яких належать: неповне усвідомлення нашого суспільства сутності інституту угод (враховуючи відсутність практики його застосування до 2012 року); намагання законодавця поєднати зарубіжні практики застосування угод різних країн, які не завжди співвідносяться; бюрократичні перепони для процесуального керівника щодо можливості укладання угод та інше.

Що стосується діяльності прокуратури під час застосування інституту угод у кримінальному процесуальному законодавстві, варто зауважити, що перетворення відбуваються як на рівні всієї іiі системи, так і на рівні завдань, функцій, повноважень прокурора в кримінальному провадженні, в тому числі й під час застосування нового для нашого суспільства інституту угод.

Тобто діяльність прокурора під час застосування угод у кримінальному провадження потребує особливої процедури, а отже й особливої уваги. У зв'язку із чим нагальною є потреба пошуку оптимального балансу між повноваженнями й процесуальними можливостями прокурора (як представника держави), пов'язаними із виконанням ним завдань під час угод у кримінальному провадженні. 


\title{
Activities of the prosecutor at the stage of pre-trial investigation in criminal proceedings based on agreements taking into account the experience of foreign countries
}

\author{
Nalyvaiko Ye. $\mathbf{O}$. \\ Candidate of Law \\ orcid.org/0000-0002-7597-8762 \\ EvgeniyNalivaiko111@gmail.com
}

Key words:

institute of agreements, reconciliation agreement, plea agreement, procedural supervisor.
The reform of the criminal process has put forward new demands on Ukrainian society and the state. The changes taking place put in a criminal process base the individual human rights and freedoms recognized as the highest values which determine the essence and purpose of the state. The European integration course chosen by Ukraine provides an opportunity to study and apply the best institutions of criminal procedures that have been operating in foreign countries for a long time.

One such institution, if properly applied and used in our opinion, is the institution of agreements in criminal proceedings, which in essence should significantly reduce the time of criminal proceedings and simplify the investigation of serious and especially serious crimes, and thus reduce the burden on the procedural supervisor and promote interests of society.

Even though this institution has been operating in our country since 2012, even now it is impossible to state a consistent practice and clear regulation of procedural rules during its application. In our opinion, this is due to several factors, which include: incomplete awareness of our society of the essence of the institution of agreements (given the lack of practice of their application until 2012); the legislator's efforts to combine the foreign practice of applying agreements of different countries, which are not always correlated with each other; bureaucratic obstacles for the procedural supervisor regarding the possibility of concluding agreements, etc.

About the activities of the prosecutor's office, when applying the institution of agreements in criminal procedural law, it should be noted that transformations occur both at the level of its entire system and tasks, functions, powers of the prosecutor in criminal proceedings, including the application of new to our society institute agreements.

That is, the activity of the prosecutor during the application of agreements in criminal proceedings requires a special procedure, and therefore special attention. Therefore, there is an urgent need to find the optimal balance between the powers and procedural capabilities of the prosecutor (as a representative of the state), related to the performance of his tasks during agreements in criminal proceedings.
Вступ. Питання кримінально-процесуальної діяльності прокурора під час укладання угод як на стадії досудового розслідування, так і в суді були предметом наукових досліджень вчених різних епох, зокрема, слід виокремити праці Ю.П. Аленіна, Ю.В. Бауліна, І.В. Басисти, В.І. Боярова, Г.П. Власової, Ю.М. Дьоміна, О.В. Капліної, М.О. Карпенко, В.М. Кравчука, Л.Б. Коваленко, О.П. Кучинської, О.О. Леляк, В.Т. Маляренка, М.М. Михеєнка, В.Т. Нора, П.Ф. Пашкевича, І.В. Рогатюка, Г.П. Середи, О.В. Рибалкі, І.А. Тітка, Л.Д. Удалової, В.П. Шибіка, О.Г. Шило, О.Г. Яновської та інших науковців.
Однак, незважаючи на значний внесок зазначених науковців, теоретичні й практичні проблеми процесуальної діяльності прокурора під час здійснення процесуального керівництва в разі застосування угод у кримінальному провадженні й досі залишаються спірними й нерозв'язаними, що й зумовило актуальність наукової статті.

Метою статті $є$ виокремлення наявних проблемних питань у діяльності прокурора під час застосування інституту угод у кримінальному провадженні в процесі досудового розслідування, наведення Європейського досвіду застосування угод у кримінальному провадженні та надання 
власних пропозицій щодо вдосконалення діяльності прокурора під час застосування як угоди про примирення, так і визнання винуватості.

Виклад основного матеріалу дослідження. Автор, безперечно, підтримає включення інституту угод до законодавства України, який, за задумом законодавця, повинен оптимізувати й спростити розгляд кримінальних проваджень незначного ступеня тяжкості й допомогти в розслідуванні тяжких та особливо тяжких злочинів.

Коротко аналізуючи правову природу застосування відновного правосуддя в кримінальному провадженні нашої держави, відзначимо, що не можна стверджувати, що такий інститут взагалі був невідомий нашому суспільству до 2012 р., адже в Україні така процедура зародилась, ще коли не існувало Сполучених Штатів Америки (далі США), в яких інститут угод наразі найбільше розвинений у світі. Тобто, якщо повернутися до джерел Київської Русі, то можна зазначити, що процес примирення, хоча й не в тому вигляді який існує натепер, але почав зароджуватися після прийняття «Руської правди», за якою визначення злочину тлумачилися як образа. Водночас одним 3 основних видів покарань у «Руській правді» був штраф, зокрема, помста зі сторони родичів убитого могла бути замінена сплатою 40 гривень. За вбивство ж представника княжої адміністрації потрібно було сплатити подвійну виру (80 гривень). «Руська правда» знає також поклепну виру й подає способи, як звільнитися від наклепу. Отже, вже під час Київської Русі були намагання законодавче закріпити норми, які могли б примірити учасників образ між собою. На жаль, надалі ці починання свого належного правового продовження не отримали та, як наслідок, не трансформувалися в готовність нашого суспільства одразу сприйняти й деякою мірою допомогти в розвитку запровадженого законодавцем інституту угод.

3 огляду на вищевикладене, вітчизняному законодавцю необхідно проаналізувати застосування інституту угод у США й у країнах Свропи, запозичивши найбільш вдалі норми 3 урахуванням нашого законодавства, таким чином запровадивши шляхом внесення необхідних змін i доповнень гнучкішу систему, яка буде полягати як у наданні ширших прав процесуальним керівникам, так і в покращенні становища сторони захисту в разі обопільної згоди щодо укладання угоди. Одразу слід відзначити, що, хоча можна прагнути розвинути застосування інституту угод в нашій країні до рівня, якого досягли США, але не можна повністю копіювати їхню модель застосування, оскільки різні правові системи країн не можуть повною мірою імплементуватися одна до одної (наприклад, в США система покарань визначена не поглинанням суворішого покарання менш суворим, а скла- данням кожного окремого епізоду, що може привести до визначення покарання понад 100 років за скоєні злочини та, як наслідок, прагнення саме підозрюваного до укладання угоди 3 меншим обсягом покарання та повного сприяння правоохоронним органам у розкритті й виявленні нових злочинів).

Тобто в США під час застосування інституту угод був за основу покладений принцип доцільності, за яким прокурор має важили впливу, непритаманні законодавству нашої країни, зокрема допустимість прокурорської тактики ведення перемовин щодо укладання угоди про визнання винуватості, яка полягає в обвинуваченні (підозрі) особи у вчиненні злочину без належних доказів; необмежена можливість для прокурора в знятті обвинувачення, що недостатньо підтверджене доказами, на фактично усіх етапах кримінального переслідування [5, с. 26-27].

Європейські країни за системою застосування інституту угод розподіляються на країни, в яких прокурор діє за принципом законності, й на країни, в яких прокурор діє за принципом доцільності. Наприклад, у Франції запроваджений принцип доцільності, прокурор наділений автономністю в прийнятті рішень, тому, як і в США, більшість фактів про вчинення злочинів, зареєстрованих у прокуратурі, не закінчуються судовим розглядом [5, с. 30-31].

У таких країнах, як Італія, Німеччина діє принцип законності, прокурор обмежений у своїх повноваженнях щодо укладання угод. Зокрема, в Італії обов' язкове кримінальне переслідування являє собою традиційну систему, а ст. 112 Конституцій Італії вказує, що прокуратура зобов’язана здійснювати кримінальне переслідування [6].

Враховуючи викладене, важливо спробувати знайти так звану «золоту середину» між застосуванням інституту угод за законодавством нашої країни й врахуванням і впровадженням корисної практики застосування угод провідних європейських країн і США. Зокрема, можна запозичити надання більшої автономії процесуальним керівникам, потерпілим під час укладання угоди, а підозрюваним гнучкішого застосування покарання в разі підтвердження суспільного інтересу й виконання вимог, передбачених у п. п. 3, 4 ч. 1 ст. 470 Кримінального процесуального кодексу (далі - КПК) України.

Крім того, слід зазначити, що навіть у США запровадження інститут угод не одразу надало той результат, до якого прагнув законодавець, зокрема, в штаті Нью-Йорк у 1839 р. угодами завершувалися 22\% судових вироків, а вже в 1920 р. - понад $80 \%$ [7, с. 626]. Тобто правовій системі США знадобилось приблизно вісімдесят років для оптимізації та сприйняття суспільством і правоохоронними органами інституту угод. 
Розглядаючи інститут угод за чинним законодавством України, відзначимо, що він поділяється на укладення угоди про примирення та укладення угоди про визнання винуватості. Водночас, якщо в укладенні угоди про визнання винуватості процесуальний керівник є центральною особою та наділений досить широкими повноваженнями, які регламентовані КПК України, то в угоді про примирення повноваження прокурора значно обмежені, що, на нашу думку, може негативно вплинути на затвердження такого виду угоди судом.

Отже, щодо угоди про примирення слід зазначити, що за чинним законодавством прокурор має лише номінальні повноваження, які обмежуються обов'язком проінформувати підозрюваному й потерпілому про їхнє право на примирення, роз'яснивши водночас механізм його реалізації. За такої умови законодавцем підкреслено, що прокурор повинен не чинити перешкод в укладанні угод про примирення, проте така думка законодавця не зовсім зрозуміла, адже особа, яка здійснює нагляд у формі процесуального керівництва, не тільки не може чинити перешкод у прийнятті будь-яких процесуальних рішень, регламентованих законом, а повинна сприяти їхньому прийнятті. Тобто останнє речення в ч. 7 ст. 469 КПК України за своєю сутністю не має правового сенсу й лише обтяжує вказану частину статті КПК України необов'язковим уточненням.

Разом із тим аналіз чинних норм законодавства, які стосуються діяльності прокурора в застосуванні угод про примирення, вказує на те, що прокурор позбавлений можливості ініціювати угоду про примирення та фактично не може вплинути чи виправити вже складену угоду про примирення між потерпілим і підозрюваним. Вважаємо, що така тактика законодавця могла б себе виправдати в разі діяльності в нашій державі інституту медіації та можливості включення професійного медіатора до переліку учасників кримінального провадження, який, крім професійної допомоги під час складання угоди, може дійсно допомогти потерпілому й підозрюваному дійти до сутності такого виду угод, а саме до примирення, яке врешті-решт повинно полягати у відновленні поваги між потерпілим і підозрюваним та у розумінні останніми, що вони приймають справедливе рішення.

Про сутність медіації зазначав ще Мартін Райт, бувши європейським експертом Ради Європи зі справ медіації та відновного правосуддя. Отже, на думку Мартіна Райта, вірним шляхом, характерним для справжнього, а не формального примирення, є роздуми потерпілого й підозрюваного над тим, що відбулося, та винесення для себе життєвих уроків. Цим правильним шляхом, який є запорукою істинному виправленню, порушник зможе пройти за активної участі медіатора, відвідуючи примірювальні зустрічі-конференції. На думку Мартіна Райта, медіатор повинен запросити порушника на таку зустріч спільно з тими людьми, які заслуговують на повагу та $є$ для нього безперечними авторитетами. На такій зустрічі порушник повинен розповісти про свої дії, які призвели до скоєння правопорушення, та вислухати думку потерпілого щодо скоєного. У багатьох випадках після цього в порушника виникає почуття сорому, а в потерпілого, відповідно, - розуміння та прощення, також потерпілий погоджується на репарацію з боку підозрюваного з метою виправлення своїх дій. Таким чином, потерпілий позбувається своїх негативних відчуттів. Усі присутні спільно виробляють план дій у контексті репарації. Фактично жоден 3 учасників кримінального провадження не володіє професійними навичками для досягнення цих процесів [3, с. 227, 233-235].

Отже, нанашудумку,довведенняінститутумедіаціїв законодавство нашої держави слід розширити повноваження прокурора, надавши йому право перевірити угоду про примирення перед направленням до суду й в разі необхідності запропонувати підозрюваному й потерпілому власні правки.

Ураховуючи викладене, можна запропонувати доповнити законодавство, що регламентує укладення угод про примирення, виклавши ч. 7 ст. 469 таким чином: Слідчий, прокурор зобов'язані проінформувати підозрюваного й потерпілого про їхнє право на примирення, роз'яснити механізм його реалізації, в разі відсутності захисника в сторін кримінального провадження прокурор має право відкласти направлення до суду обвинувального акту з підписаною сторонами угодою, перевірити їі зміст і в разі не відповідності угоди ст. 471 КПК України повернути угоду про примирення своєю постановою, в якій зазначити допущені помилки, підозрюваному й потерпілому.

Переходячи до процесуальної діяльності прокурора в кримінальному провадженні на підставі угоди по визнання винуватості, зазначимо, що, за задумом законодавця, вони повинні спростити діяльність як процесуальних керівників, так і суду, значно скорочуючи розгляд кримінального провадження, допомогти в розслідуванні тяжких та особливо тяжких злочинів, що повинно влаштувати й допомогти всім сторонам кримінального провадження.

Можна вказати, що задум законодавця щодо укладання угод про визнання винуватості збігається $з$ думкою Європейського Суду з прав людини (далі - ССПЛ), зокрема в п. 90 Рішення «Нацвлішвілі та Тогонадзе проти Грузії» від 24 квітня 2014 р. (заява № 9043/05) зазначено, що Суд приєднується до ідеї про те, що угоди про визнання провини, окрім надання важливих переваг швид- 
кого розгляду кримінальних справ і пом'якшення навантаження на суди, прокурорів та адвокатів, також у разі правильного їх застосування можуть стати успішним інструментом у боротьбі з корупцією та організованою злочинністю та можуть сприяти зниженню кількості призначених покарань та, як наслідок, кількості ув'язнених.

Крім того, ЄСПЛ вказує, що особа 3 власної волі може відмовитися від певних гарантій, якщо вважає, що це буде їй вигідніше надалі.

Так, у п. 91 Рішення ССПЛ «Нацвлішвілі та Тогонадзе проти Грузії» від 24 квітня 2014 р. (заява № 9043/05) зазначено, що, якщо наслідком угоди про визнання провини є те, що кримінальна справа проти підсудного розв'язується шляхом скороченого судового провадження, це становить по суті відмову від низки процесуальних прав. Це саме по собі не є проблемою, оскільки ані буква, ані дух ст. 6 не заважають особі з власної волі відмовитися від цих гарантій. Разом із тим основоположним принципом $є$ й те, що будьяка відмова від процесуальних прав для того, щоб вона була ефективною для цілей Конвенції, повинна завжди встановлюватися в недвозначній формі й супроводжуватися мінімальними гарантіями, співмірними 3 іï важливістю. Крім того, вона не повинна йти всупереч із будь-яким важливим суспільним інтересом [4].

П. 73. Рішення ЕСПЛ «Нацвлішвілі та Тогонадзе проти Грузії» від 24 квітня 2014 р. (заява № 9043/05) зазначає, що майже в усіх досліджених країнах, із можливим винятком Румунії, визнання провини обвинуваченим може бути використане лише для цілей угоди про визнання провини. Якщо угода про визнання провини не укладається або відхиляється судом, заява про визнання провини або визнавальні свідчення обвинуваченого не можуть бути використані проти нього [4]. Можна відзначити, що законодавство України в цілому відповідає п. п. 91, 73 Рішення ЄСПЛ «Нацвлішвілі та Тогонадзе проти Грузії».

Аналіз чинного законодавства України щодо порядку застосування угоди про визнання винуватості, а також повноважень, якими наділений прокурор у цій сфері, дозволяє зробити висновок, що участь прокурора в кримінальному провадженні на підставі угод реалізується в різних формах, які залежать від етапів застосування такої процедури. У кримінальному провадженні на підставі угод можна умовно виділити три етапи - етап підготовки й укладення угоди, етап затвердження угоди судом та етап виконання угоди. У межах статті проаналізуємо саме діяльність прокурора під час підготовки й укладення угоди про визнання винуватості.

Розглядуючи норми КПК України, які регламентують діяльність прокурора під час укладання угод, необхідно запропонувати визначити чіткі критерії співпраці між прокурором і підозрюваним. Це повинно сприяти завданням кримінального провадження та допомогти процесуальними керівниками розглянути укладення угоди про визнання винуватості не як можливість закінчити кримінальне провадження, що може мати проблемні питання під час судового розгляду по суті.

Тобто для більшого розуміння укладання угоди про визнання винуватості необхідно проаналізувати ч. 1 ст. 470 КПК України, в якій саме й зазначені вимоги, якими повинен керуватися процесуальний керівник, розв'язуючи для себе питання наявності підстав та обставин, необхідних для укладання угоди. Так, згідно із ч. 1 ст. 470 КПК України необхідно враховувати:

1) ступінь i характер сприяння підозрюваного в проведенні кримінального провадження щодо нього або інших осіб повинно оцінюватися процесуальним керівником не лише шляхом визнання вини особою, а насамперед у залежності від отриманої інформації, іiі позитивного впливу на здійснення розслідування, його пришвидшення та отримання нових доказів, які впливають на повноту й всебічність розслідування;

2) характер і тяжкість обвинувачення (за таким пунктом процесуальний керівник повинен оцінити, чи можна за характером обвинувачення запропонувати укладання угоди й чи дійсно, враховуючи тяжкість обвинувачення, угода буде законною та переваги від іiі укладання будуть більшими ніж завдана шкода суспільству й потерпілому, який не заперечує проти їі укладання);

3) наявність суспільного інтересу в забезпеченні швидкого досудового розслідування та судового провадження, викритті більшої кількості кримінальних правопорушень. Щодо такого пункту слід переділити увагу насамперед терміну «наявність суспільного інтересу». Так, у своїй Постанові Пленуму Вищого спеціалізованого суду України «Про практику здійснення судами кримінального провадження на підставі угод» від 11 грудня 2015 р. № 13 Суд вказав, що терміни «громадські інтереси» й «суспільні інтереси» в контексті КПК України слід розуміти як тотожні [2]. Однак чіткого визначення жодного із цих термінів немає.

Ще одне поняття, що виникло 3 практики застосування угоди про визнання винуватості, - це поняття обов'язку особи «співпрацювати 3 правоохоронними органами». Зокрема, у справі № 127/13672/18 Вінницький міський суд Вінницької області своєю ухвалою від 4 листопада 2019 р., що набрала законної сили, вказав, що відсутність конкретизації сутності таких зобов'язань iз використанням лише загальних формулювань унеможливлює суд пересвідчитися в реальності й можливості їх виконання, у зв'язку із чим, 3 огляду на передбачені ст. 476 КПК наслідки неви- 
конання угоди, такий виклад є неприпустимим, а тому Суд дійшов висновку про наявність очевидної неможливості виконання обвинуваченою особою взятих на себе за угодою зобов'язань співпрацювати 3 правоохоронними органами, оскільки в угоді не визначено, в чому саме полягає ця співпраця, в межах якого кримінального провадження та які дії повинен вчинити обвинувачений [7].

Виносячи вказане рішення, суд фактично керувався нормами Постанови Пленуму Верховного спеціалізованого суду України з розгляду цивільних і кримінальних справ № 13 від 11 грудня 2015 р. «Про практику здійснення судами кримінального провадження на підставі угод», відповідно до абз. 3 п. 10 якої в питанні, що стосується обов'язків підозрюваного чи обвинуваченого щодо співпраці у викритті кримінального правопорушення, вчиненого іншою особою, в будьякому разі обов'язки підозрюваного, обвинуваченого мають бути зазначені в такий спосіб, щоб можна було пересвідчитися в реальності й можливості їх виконання [2].

Водночас у справі № 643/15775/18 Суд у своєму рішенні від 15 січня 2019 р. взяв до уваги домовленості щодо співпраці у викритті іншої особи у вчиненні кримінального правопорушення у сфері обігу наркотичних засобів 3 огляду на те, що внаслідок співпраці відносно іншої особи внесено відомості до Єдиного реєстру досудових розслідувань [8]. Отже, в такому випадку в змісті угоди було конкретизовано, що повинна заробити особа (викрити іншу), й наявна інформація щодо конкретних дій особи на виконання вимог угоди.

Тобто, аналізуючи рішення суду, можна дійти висновку, що він вимагає від процесуального керівника в змісті угоди про визнання винуватості уникати широкого змісту трактування поняття «співпраці 3 правоохоронними органами», а навпаки, конкретно зазначати сутність співпраці особи $з$ правоохоронними органами.

Проаналізувавши практично всі норми ст. 470 КПК України, можна зробити висновок, що згідно з їі змістом передбачена необхідність перевірки прокурором наявних пунктів статті в їх сукупності. Тому під час розв'язання питання щодо можливості ініціювання угоди про визнання винуватості прокурор повинен оцінити кожний iз зазначених пунктів у ст. 470 КПК України й тільки після цього прийняти рішення про необхідність укладання угоди про визнання винуватості. Однак слід зазначити, що не завжди всі норми ч. 1 ст. 470 КПК України процесуальний керівник має можливість врахувати в їх сукупності, адже за певним видами злочину особа, яка підозрюється в його скоєнні, навіть за своїм бажанням не в змозі виконати п. п. 3, 4 ч. 1 ст. 470 КПК України.

3 огляду на зазначене пропонуємо доповнити ст. 470 КПК України ч. 2 й викласти таким чином:

1) наявність суспільного інтересу в п. п. 3, 4 ч. 1 ст. 470 оцінюється процесуальним керівником і полягає в належному підтвердженні запобігання, викриття, виявлення чи припинення кримінальних правопорушень, у тому числі й більш тяжких.

2) у разі відсутності в сторони обвинувачення можливості виконати п. п. 3, 4 ч. 1 ст. 470 КПК України щодо належного підтвердження запобігання, викриття, виявлення чи припинення кримінальних правопорушень, у тому числі і більш тяжких, необхідно оцінити користь, яку отримають від укладання угоди не лише сторони укладання угоди, а й суспільство;

3) у разі обгрунтування необхідності укладання угоди про визнання винуватості метою викрити більшу кількість кримінальних правопорушень чи належним підтвердженням запобігання, викриття, виявлення чи припинення кримінальних правопорушень, у тому числі й більш тяжких, необхідно в змісті угоди застосовувати конкретну визначеність дій особи задля досягнення зазначеної мети.

Висновки 3 дослідження. Враховуючи викладене, можна вказати, що в разі вірного застосування та необхідного вдосконалення інститут угод повинен зайняти важливе місце під час здійснення кримінального провадження в нашій державі. Водночас наразі використання такого інституту повною мірою не відбувається, а отже, норми законодавства, які відповідають за укладання угод у кримінальному провадженні, потребують покращення шляхом внесення змін і доповнень до законодавства, що регламентують як діяльність працівників прокуратури, так і діяльність суб'єктів кримінального провадження.

\section{Література}

1. Кримінальний процесуальний кодекс України : Закон України від 13 квітня 2012 р. № 4651-VI / Верховна Рада України. URL: https://zakon.rada.gov.ua/laws/show/4651-17 (дата звернення: 29.09.2020).

2. Про практику здійснення судами кримінального провадження на підставі угод : Постанова Пленуму Вищого спеціалізованого суду України від 11 грудня 2015 р. № 13. База даних «Законодавство України». URL: https://zakon.rada.gov.ua/laws/show/v0013740-15\#Text (дата звернення: 29.09.2020).

3. Райт Мартин. Восстановительное правосудие - путь к справедливости. Симпозиум / пер. с англ. Киев : Издатель Захаренко В.А., 2007. 304 с.

4. Рішення Європейського суду з прав людини «Нацвлішвілі та Тогонадзе проти Грузії» від 24 квітня 2014 p. URL: http://hudoc.echr.coe.int/rus?i=001-142672 (дата звернення: 24.09.2020). 
5. Ma Y. Prosecutorial discretion and plea bargaining in the United States, France, Germany and Italy: a comparative perspective. International Criminal Justice Review. 2002. Volume 12. P. 22-52.

6. Конституція Італії. URL: http://www.senato.it/documenti/repository/ istituzione/costituzione_inglese. pdf (дата звернення: 24.09.2020).

7. Бернам У. Правова система США. 3-й випуск. Москва : Новая юстиция, 2006. 1216 с.

8. Рішення Вінницького міського суду Вінницької області від 03 вересня 2018 р. Сдиний державний реєстр судових рішень. URL: http://www.reyestr.court.gov.ua/Review/76300073 (дата звернення: 24.09.2020).

9. Рішення Московського районного суду м. Харкова від 15 січня 2019 р. Єдиний державний реєстр судових рімень. URL: http://www.reyestr.court.gov.ua/Review/79178168 (дата звернення: 24.09.2020).

\section{References}

1. Kryminalnyi protsesualnyi kodeks Ukrainy [The Criminal Procedure Code of Ukraine]: Zakon Ukrainy [Law of Ukraine] vid 13 kvitnia 2012 roku № 4651-VI. URL: http://zakon2.rada.gov.ua/laws/ show/4651-17 (accessed: 29.09.2020)

2. Postanova Plenumu Vyshchoho spetsializovanoho sudu Ukrainy "Pro praktyku zdiisnennia sudamy kryminalnoho provadzhennia na pidstavi uhod" vid 11.12.2015 № 13: [Resolution of the Plenum of the Supreme Specialized Court of Ukraine "On the practice of criminal proceedings by courts on the basis of agreements" of 11.12.2015 № 13:] URL: https://zakon.rada.gov.ua/laws/show/v0013740-15\#Text (data zvernennia: 29.09.2020) [date of application 29.09.2020].

3. Rajt Martyn Vosstanovytelnoe pravosudye - put k spravedlyvosty. [Restorative justice is the path to justice] Sympozyum / Rajt Martyn. - [per. s anhl.]. K.: Yzdatel Zakharenko V.A., 2007. 304 s.

4. Rishennya Yevropejskoho sudu z prav lyudyny "Nacvlishvili ta Tohonadze proty Hruziyi” vid 24.04.2014 r. [Judgment of the European Court of Human Rights "Natsvlishvili and Togonadze v. Georgia" of 24.04.2014] URL: http://hudoc.echr.coe.int/rus?i=001-142672 (data zvernennya: 24.09.2020) [date of application: 24.04.2014].

5. Ma Y. Prosecutorial discretion and plea bargaining in the United States, France, Germany and Italy: a comparative perspective / Y. Ma // International Criminal Justice Review. 2002. Volume 12. P. 22-52.

6. Konstytutsiia Italii [Italian Constitution] URL: http://www.senato.it/documenti/repository/ istituzione/ costituzione inglese.pdf (data zvernennia: 24.09.2020) [date of application: 24.09.2020].

7. Bernam U. Pravova systema SShA $3-y$ vypusk [The USA justice system $3^{\text {rd }}$ issue] / U. Bernam. M. : Novaya yustyciya, 2006. $1216 \mathrm{~s}$.

8. Rishennia Vinnytskoho miskoho sudu Vinnytskoi oblasti vid 03.09.2018 r. [Resolution of the Vinnytsia City Court of the Vinnytsia Oblast from 03.09.2018] URL: http://www.reyestr.court.gov.ua/ Review/76300073 (data zvernennya: 24.09.2020) [date of application: 24.09.2020].

9. Rishennia Moskovskoho raionnoho sudu m. Kharkova vid 15.01.2019 r. [Resolution of the Moscow District Court of Kharkiv from 15.01.2019] URL: http://www.reyestr.court.gov.ua/Review/79178168 (data zvernennya: 24.09.2020) [date of application: 24.09.2020]. 